\title{
LIST OF PUBLICATIONS ON RESEARCH \\ AT \\ UNIVERSITY OF WYOMING- \\ NATIONAL PARK SERVICE RESEARCH CENTER
}

\section{Altmann, Margaret}

1951 Patterns of herd structure in free-ranging elk. Abstr. Anat. Rec., 3(3): 74 .

1952 Social behavior of elk, Cervus canadensis nelsoni, in the Jackson Hole area of Wyoming. Behavior, 4(2): 116-143.

1953 Social graces in elk society. Bull. N. Y. Zool. Soc., Animal Kingdom, 56(3): 66-72.

1956 Patterns of herd behavior in free-ranging elk of Wyoming, Cervus canadensis nelsoni. Zoologica, $41(2)$ : 65-71.

Two marking devices for large land mammals. Jour. of Wildl. Mgmt., 20(4): 464. With Richard D. Taber and Anton de Vos.

Patterns of social behavior in big game. Trans. of the 21 st No. Amer. Wildl. Conf., March 5-7, 1956. pp. 538-545.

1958 The flight distance in free-ranging big game. Jour. of Wildl. Mgmt., 22(2): 207-209.

Social integration of the moose calf. Animal Behaviour, $6(3-4): 155-159$.

1959 Group dynamics in Wyoming moose during the rutting season. Jour. of Mammal., 40(3): 420-424.

1960 Moose runs from Sandhill Crane. J. of Mammal., 41 (4): 525. The role of juvenile elk and moose in the social dynamics of their species. Zoologica, 45, Pt. 1: 35-39.

1961 "Teen-age" problems in the wilderness. Animal Kingdom, 64(2): $41-44$.

1963 Naturalistic studies, of maternal care in moose and elk. Chapter in Maternal Behavior in Mammals, Ed. by Harriet L. Rheingold. John Wiley \& Sons, pp. 233-253.

Seniors of the wilderness. Animal Kingdom, 66(6): 181-183.

1965 Messages in the wild. Animal Kingdom, 68(6): 179-182.

1968 Social conduct in and out of the herd. Colo. Quarterly, 16(4): 335- 351 . 
Armitage, Kenneth B.

1959 Behavior patterns of juvenile yellow-bellied marmots (Marmota flaviventris nosophora Howel1). Anat. Rec., 134(3): 529.

1961 Frequency of melanism in the golden-mantled marmot. J. of Mammal., $42(1):$ 100-101.

1962 Social behavior of a colony of the yeliow-bellied marmot (Marmota flaviventris). An. Behav., 10(3-4): 319-331.

Bangham, Ralph

1951 Parasites of $\mathrm{fish}$ in the Upper Snake River drainage and in Yellowstone Lake, Wyoming. Zoologica, 36(111).

1953 Studies on monogenetic trematodes: Dactylogyridae from Alaska, Wisconsin and Wyoming. Am. Mid. Nat., 50(1): 206-217. Published by John D. Mizelle and Francis 0 . Webb using Bangham's material.

Hypocaryophyllaeus gilae n. sp. (Cestoda: Caryophyllaeidae) from the Utah chub, Gila atraria, in Wyoming. Proc. Helm. Soc. Wash., 20(2): 113-117. Published by Jacob H. Fischthal using Bangham's material.

Baxter, John W.

1960 Aquatic Hyphomycetes from Wyoming. Mycologia, 52(4): 654-655.

Beetle, Alan A.

1952 A 1951 survey of summer elk range in the Teton Wilderness area. Wyoming Range Manage. 51: 1-5.

1957 A study of range condition classes in the Jackson Hole region of Wyoming. Wyoming Range Management Issue No. 104. (Mimeo)

1959 New names within the section Tridentatae of Artemisia. Rhodora $61: 82-85$.

1960 A Study of Sagebrush. Bulletin 368, University of Wyoming Agricultural Experiment Station, June.

1961 Range Survey in Teton County, Wyoming. Part I. Ecology of Range Resources. Bulletin 376, University of Wyoming Agricultural Experiment Station, March.

1962 Range Survey in Teton County, Wyoming. Part II. Utilization and Condition Classes, Bulletin 400, University of Wyoming Agricultural Experiment Station, December.

1964 (With Fronk, W. D. and D. G. Fullerton) Dipterous gall on the Artemisia tridentata complex and insects associated with them. Ann. Entomological Soc. of America 57: 575-577.

1966 A 1966 survey of summer elk range in southern Yellowstone. Wyoming Range Manage. 223: 196-198.

(With Alvin Young) A third spubspecies in the Artemisia tridentata complex. Rhodora 67: 405-406. 
1968 Range Survey in Teton County, Wyoming. Part 111 . Trends in Vegetation. Research Journal 26, University of Wyoming Agricultural Experiment Station, December.

Another note on sagebrush taxonomy. Rhodora 70: 782.

1970 Ecology and carrying capacity of summer elk range. In Forestry Research Progress in 1970. Mclntyre-Stennis, pages 34-35, 11 lus.

(With M. May) Grasses of Wyoming. Wyoming Agric. Exper. Sta. Res. Jour. 39: 1-151.

Recommended plant names. Wyoming Agric. Exper. Sta. Research Journal 31: 1-124.

1971 M. \& O. Murie's "Wapati Wilderness". Wyoming Range Manage. 286: page 12. (Book Review)

1972 Variation and ecology of aspen. Forestry Research Progress in 1971. page 51.

Beetle, Dorothy E.

1956 Habitats of terrestrial Mollusca in Jackson Hole, Wyoming. Jour. Colo-Wyo Acad. Sci., 55(8): 43.

1957 The Mollusca of Teton County, Wyoming. The Nautilus, 71(1): $12-22$.

1960 Noteworthy records of Wyoming Mollusca. The Nautilus, 73(4): $155-157$.

A checklist of Wyoming recent Mollusca. Sterkiana, No. 3.

Bergstrom, Robert C.

1975 The prevalence of Dictyocoulus Viviparus infection in Rocky Mountain elk in Teton County, Wyoming. J. Wildl. Dis., 11:40-44.

Bick, George H. and Lothar E. Hornuff

1972 Odonata collected in Wyoming, South Dakota, and Nebraska. Proc. Ent. Soc. of Washington, 74(1): 1-8.

Bliss, L. C.

1956 A comparison of plant development in microenvironments of arctic and alpine tundras. Ecol. Mon., 26: 303-337.

Calder, William A., Jr.

1968 Temperature relations and underwater endurance of the smallest homeothermic diver. Amer. Zoologist, 8(4): 145.

1969 Temperature relations and underwater endurance of the smallest homeothermic diver, the water shrew. Comp. Biochem. Physiol., 30: 1075-1082.

1971 Temperature relationships and nesting of the Calliope Hummingbird. The Condor, 73(3): 314-321.

1976 Energy Crisis of the Hummingbird. Natural History, 85(5): 24-29.

\section{Carpenter, Charles}

1953 Aggregation behavior of tadpoles of Rana p. pretiosa. Herpetologica, 9: 77-78. 
An ecological survey of the herpetofauna of the Grand TetonJackson Hole area of Wyoming. Copeia, 3: 170-174.

Trapping technique for aquatic salamanders. Herpetologica, 8: 183.

1954 A study of amphibian movement in the Jackson Hole Wildlife Park. Copeia, 3: 197-200.

Clark, M. L. and T. W. Clark

1971 Key to 22 selected flowering plants based on leaf epidermal morphology from Jackson Hole, Wyoming. Wyo. Range Mgmt., 288: $52-60$.

Clark, T. W.

1971 Aberrant coloration in Microtus pennsylvanicus from Grand Teton National Park, Wyoming. Northwestern Science.

Seasonal activity, habitat, reproduction and food uses of the western jumping mouse in Grand Teton National Park, Wyoming. Northwestern Science.

1973 Distribution and reproduction of shrews in Grand Teton National Park, Wyoming. Northwestern Sci., 47: 128-131.

1975 Ecological notes on deer mice in Grand Teton National Park, Wyoming. Northwestern Sci., 49:

Body measurements of Western jumping mice from Northwestern Wyoming. Northwestern Sci., 49:

Craighead, Frank $C$.

1951 A biological and economic evaluation of coyote predation. N.Y. Zool. Soc. and the Conservation Found. July (booklet)

Craighead, Frank C. and John J. Craighead

1949 Nesting Canada geese on the Upper Snake River. Jour. Wildl. Mgmt., 13(1): 51-64.

1950 The ecology of raptor predation. Trans. 15th No. Amer. Wildl. Conf., pp. 209-223.

Craighead, John J.

1952 A biological and economic appraisal of the Jackson Hole elk herd. N. Y. Zool. Soc. and the Conservation Found. (booklet) November.

Cummins, George B. and John W. Baxter

1962 Nomenclature, life histories, and records of North American Uredinales. Madrono, 16(6): 201-203.

Czaplewski, R. L.

1972 Evolution of terminal consumers in a steady state regime. M. S. Thesis, Univ. Wyoming. 54 pp. 
Czaplewski, R. L. and M. Parker Use of a BOD oxygen probe for estimating primary productivity. Limnology and Oceanography, In Press.

Denniston, R. H.

1948 Certain aspects of the behavior of the Wyoming moose. Jour. Colo.-Wyo. Acad. of Sci., 3(6): 55.

1949 The development of a calf moose. Jour. Colo-Wyo Acad. of Sci., $4(1): 58$.

1956 Ecology, behavior and population dynamics of the Wyoming or Rocky Mountain moose, Alces alces shirasi. Zoologica, 41(3): 105-118.

Diem, Kenneth L.

1967 Banding Studies of Water Birds on the Molly. I slands, Yellowstone Lake, Wyoming. Yellowstone Library and Museum Association, Yellowstone National Park. 41 pp. (With David Del. Condon)

Dimmick, Ralph W.

1968 Canada Geese of Jackson Hole. Bull. No. 11, Wyoming Game and Fish Commission, Cheyenne, Wyoming. 86 pp.

Edwards, William C.

1964 A preliminary investigation concerning the plant ecology fo the willow flats on Jackson Lake, Jackson Hole, Wyoming. Proc. 74 th Annual Meeting of the Nebr. Acad. of Sciences, May $1 \& 2$, pp. 6-7.

Emlen, John T.

1952 Social behavior in nesting cliff swallows. The Condor, 54: 177-199.

1954 Territory, nest building, and pair formation in the cliff swallow. The Auk, Vol. 71.

Evans, Howard E.

1962 The geyser-loving digger wasps of Yellowstone. The Explorer Cleveland, Ohio, 4: 6-11.

1963 Predatory wasps. Scientific American, 208(4): 145-154. April. The clustering wasps--and why they cluster. Audubon Mag., 65(4): 236-237. July-August.

Notes on the prey and nesting behavior of some solitary wasps of Jackson Hole, Wyoming. Entomological News, $74(9)$ : 233-239.

1964 Observations on the ethology of digger wasps of the genus Steniolia (Hymenoptera: Sphecidae: Bembicini). Amer. Mid. Nat., 72(2): 257-280. (With J. E. Gillaspy)

1965 Simultaneous care of more than one nest by Ammophila azteca

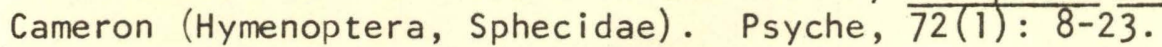


1966 The Comparative Ethology and Evolution of the Sand Wasps. Harvard Univ. Press, 526 pp.

The accessory burrows of digger wasps. Science, 152(3721): 465-471.

Nests and prey of two species of Philanthus in Jackson Hole, Wyoming (Hymenoptera, Specidae). Great Basin Naturalist, 26 $(1-2): 35-40$

1968 The hunt of the wasps at Jackson Hole. Natural History, 77: 38-39.

1970 Ecological-behavioral studies of the wasps of Jackson Hole, Wyoming. Bull. Mus. Comp. Zool., 140(7): 451-511.

Findley, James $S$.

1951 Habitat preferences of four species of Microtus in Jackson Hole, Wyoming. Jour. Mammal., 32(1): 118-120.

A record of moose speed. Jour. Mammal., 32(1): 116.

A tame red fox cub. Jour. Mammal., 32(1): 117.

1954 Reproduction in two species of Myotis in Jackson Hole, Wyoming. Jour. Mammal., 35(3): 434.

Flack, J. A. Douglas

1970 Bird populations of aspen forests in Western North America. University of Wisconsin. (Abstract, Ph.D. Thesis) Microfilm of photocopies available.

French, Norman R.

1955 Foraging behavior and predation by Clark Nutcracker. The Condor, 57(1): 61-62.

1959 Life history of the Black Rosy Finch. The Auk, 76(2): 159-180. Distribution and migration of the Black Rosy Finch. The Condor, 61 (1): 18-29.

Gilligan, James $P$.

1954 Wildlife values in western wilderness area management. Jour. Wildl. Mgmt., 18(4).

Gould, Edwin, Norman C. Negus and Alvin Novick

1964 Evidence for echolocation in shrews. J. Exp. Zool., 156(1):19-38.

Gourley, R. S. and F. J. Jannett, Jr.

1975 Pine and montane vole age estimates from eye lens weights.

J. Wildlife Management, 39: 550-556.

Houston, Douglas B.

1968 The Shiras Moose in Jackson Hole, Wyoming. Grand Teton Nat. Hist. Assoc. Tech. Bull. \#1. 110pp.

1969 Immobilization of the Shiras Moose. Jour. Wildl. Mgmt., 33(3): 534-537. 
Huckabee, John W., Frederick 0. Cartan and Garth S. Kennington

1972 Environmental influence on trace elements in hair of 15 species of mammals. Oak Ridge National Laboratory, ORNL-TM-3747. 38 pp.

Jannett, F. J., Jr.

1975 The "hip glands" of Microtus pennsylvanicus and M. Iongicaudus (Rodentia: Muridae), voles "without" hip glands. Systematic Zoology, 24: 171-175.

Jannett, F. J., Jr. and J. Z. Jannett

1974 Drum-marking by Arvicola richardsoni and its taxonomic significance. American Midland Naturalist, 92: 230-234.

John, Kenneth R.

1957 Comparative rates of survival of normal and deformed chub, Gila atraria Girard, in Two Ocean Lake, Teton County, Wyoming.

Proc. Pa. Acad. of Science, 31 : 77-82.

1959 Ecology of the chub, Gila atraria with special emphasis on vertebral curvatures in Two Ocean Lake, Teton National Park, Wyoming. Ecology, 40(4): 564-571.

Jones, Webster B.

1965 Response of major plant species to elk and cattle grazing in Northwestern Wyoming. J. of Range Mgmt., 18(4): 218-220.

Kennington, Garth S.

1957 Influence of altitude and temperature upon rate of oxygen consumption of Tribolium confusum Duval and Camponotus pennsylvanicus modoc Wheeler. Physiol. Zool., 39(4): 305-314.

1961 The influence of temperature and atmospheric pressure on the rate of oxygen uptake in Tribolium confusum. Ecology, 42(1): 212-215.

Kroger, Richard L.

1970 An annotated list of stream invertebrates collected from Grand Teton National Park, Wyoming. U. of Wyo. Publ., 36(1): 1-14. July 15.

Laycock, William

1953 Ecological notes on the pocket gopher in Wyoming. Jour. ColoWyo. Acad. of Sci., 4(5): 41 .

1957 Seasonal periods of surface inactivity of the pocket gopher. Jour. of Mammal., 38(1): 132-133.

1958 The initial pattern of revegetation of pocket gopher mounds. Ecology, 39(2): 346-351.

Levi, Herbert $W$. and Lorna R. Levi

1951 Report on a collection of spiders and harvestmen from Wyoming and neighboring states. Zoologica, 36(LV): 219-237. 
Lichtwardt, Robert W.

1967 Zygospores and spore appendages of Harpella (Trichomycetes) from larvae of Simuliidae. Mycologia, 59(3): 482-491.

1972 Undescribed genera and species of Harpellales (Trichemycetes) from the guts of aquatic insects. Mycologia 64 (1): 167-197.

Lowrie, Donald C.

1955 A list of the spiders of the Grand Teton Park area, with descriptions of some new North American spiders. Amer. Museum Novitates, No. 1736: 1-29 (With Willis J. Gertsch)

1967 Some life history data on several species of common spiders from the Jackson Hole area of Wyoming. Bull. So. Calif. Acad. of Sci., 66(2): 142-146.

1968 The spiders of the herbaceous stratum of the Jackson Hole region of Wyoming. Northwest Science, 42(3): 89-100.

MacLeod, Ellis G.

1971 Studies on the biology of the Chrysopidae. 11. The feeding behavior of the adult of Chrysopa carnea (Neuroptera). Psyche, 78(1-2): 107-121. (Wi th Joseph K. Sheldon).

McHugh, Tom

1958 Social behavior of the American buffalo (Bison bison bison). Zoologica, 43, Pt. 1, No. 1, pp. 1-40 (entire issue) April 1958.

McKnight, Kent $H$.

1969 A note on Discina. Mycologia, 61(3): 614-630. May-.lune.

1971 On two species of false morels (Gyromitra) in Utah. Great Basin Naturalist, $31(2): 35-47$.

Miller, Dwight D.

1955 A study of sex combs in Drosophila affinis and Drosophila athabasca. Trans. of the Amer. Microscop. Soc., 74(2): 191-197.

Nakamura, Mitsuru

1950 A survey of Pasteurella tularensis infection in the animals of the Jackson Hole area. Zoologica, 35(11): 129-131.

Negus, Norman C.

1950 Breeding of three-year-old females in the Jackson Hole Wildife Park buffalo herd. Jour. of Mammal., 31 (4): 463.

Fluctuation in the population of Neotoma cinerea (woodrat) in Jackson Hole, Wyoming. Jour. of Mammal., 31(2): 196-197.

Habitat adaptability of Phenacomys in Wyoming. Jour. of Mammal., $31(3): 351$.

1959 Mammals of Jackson Hole, Wyoming. Jour. of Mammal., 40(3): 371-381. (With James S. Findley) 
1971 Pineal weight response to a dietary variable. Experientia, 27(2): 215-216. (With Patricia J. Berger)

Activity rhythms in Microtus montanus: the role of the pineal gland. Submitted to Journal of Experimental Zoology. (Wi th Patricia J. Berger)

The dynamics of Microtus montanus populations in Jackson Hole, Wyoming from 1960-1970.

Noble, Glenn A.

1953 An intestinal amoeba from the prong-horned antelope. Trans of the Amer. Microscop. Soc., 72 (3): 249-252.

1958 Coprozoic protozoa from Wyoming mammals. J. Protozool., 5(1): 69-74.

1961 Stress and Parasitism. 1. A preliminary investigation of the effects of stress on ground squirrels and their parasites. Exper. Parasit., $11(1):$ 63-67.

1962 Stress and Parsitism. II. Effect of crowding and fighting among ground squirrels on their Coccidia and Trichomonads. Exper. Parasit., 12(5): 368-371.

1966 Stress and Parasitism. III. Reduced night temperature and the effect on pinworms of ground squirrels. Exper. Parasit., 18(1): 61-62.

Stress and Parasitism. IV. Cold stress and Entamoeba. Exper. Parasit., 19(3): 264-268.

Patterson, Robert L.

1952 Sage Grouse in Wyoming. Sage Books, Denver, Colorado.

Pinter, Aelita J.

1965 Effects of nutrition and photoperiod on reproductive physiology of Microtus montanus. Amer. J. Physiol., 280: 633-638. (With N. C. Negus)

Litter sizes of Microtus montanus in the laboratory. J. Mammal., 46: 434-437. (With N.C. Negus).

1966 Responses of Microtus montanus to plants and plant extracts in the diet. J. Mamma1., 47: 596-601. (Wi th N. C. Negus)

1968 Effects of diet and light on growth, maturation and adrenal size of Microtus montanus. Amer. J. Physiol., 215: 461-466.

Hair growth responses to nutrition and photoperiod in the vole, Microtus montanus. Amer. J. Physiol., 215: 828-832.

1970 Hereditary hairlessness in the montane vole, Microtus montanus. J. Heredity, 61: 112-114. (Wi th A. K. McLean)

1971 Coat color mutations in two species of the vole (Microtus

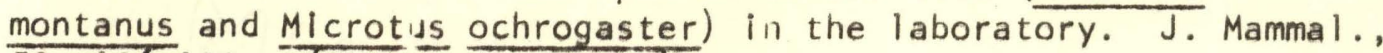
52: 196-199. (With N. C. Negus) 
1972 A new naturally occurring dominant mutation in Microtus montanus from Jackson Hole, Wyoming. Annual Meeting of the American Society of Mammalogists, Tampa, Florida, 18-22 June, 1972 (Abstract).

1973 Pink-eyed dilution in a natural population of the Uinta ground squirrel. J. Heredity, $64(2): 106$.

1974 Some aspects of population dynamics in the mountain vole, Microtus montanus (Rodentia). First International Theriological Congress, Moscow, USSR, 6-12 June, 1974 (Abstract).

Pontius, R. A.

1972 Studies on the uptake of nitrate and ammonium by phytoplankton. M.S. Thesis, Univ. Wyoming. $124 \mathrm{pp}$.

Pontius, R. W. and M. Parker

1972 Food habits of the Mountain Whitefish, Prosopium williamsoni (Girard). In revision for Transactions of the American Fisheries Society.

Rausch, Robert

1949 Paradilepis simoni n. sp., a cestode parasitic on the osprey. Zoologica, 34(1).

A contribution to the study of North American cestodes of the genus Paruterina Fuhrmann, 1906. Zoologica, 34(1). (With Everett Schiller).

Reed, John F.

1948 Botanical investigations in the Jackson Hole Wildlife Park. Jour. Colo-Wyo Acad. of Sci., 3(6): 40.

1950 The meadows of the Jackson Hole Wildlife Park. Jour. Colo-Wyo Acad. of Sci., 4(2): 53 .

1952 The vegetation of the Jackson Hole Wildlife Park, Wyoming. Am. Mid. Nat., 48(3): 700-729.

Roofe, Paul G.

1960 The rate of flow of blood through capillaries in the olfactory lobe of the brain of Amblystoma tigrinum. Anat. Rec., 138(2): 159-162.

1961 Blood constituents of Amblystoma tigrinum. Anat. Rec., 140(4): 337-340.

Weights and linear measurements of the body and of some organs of the tiger salamander. Anat. Rec., 141(1): 35-44. (With Homer B. Latimer and Lily S. Feng).

1964 Weights and linear measurements of the body and organs of the tiger salamander, before and after metamorphosis, compared with the adult. Anat. Rec. 148(2): 139-147. 
Salt, George W.

1957 An analysis of avifaunas in the Teton Mountains and Jackson Hole, Wyoming. The Condor, 59(6): 373-393.

Scherba, Gerald

1961 Nest structure and reproduction in the mound-building ant Formica opaciventris Emery in Wyoming. J. of the N. Y. Ent. Soc., 69: 71-87.

1963 Population characteristics among colonies of the ant Formica opaciventris Emery (Hymenoptera: Formicidae). J. of the N. Y. Ent. Soc., 71: 219-232.

1964 Analysis of inter-nest movement by workers of the ant Formica opaciventris (Hymenoptera: Formicidae). An. Behav., 12(4): 508-512.

Species replacement as a factor affecting distribution of Formica opaciventris Emery (Hymenoptera: Formicidae). J. of the N. Y. Ent. Soc., 72: 231-237.

Analysis of inter-nest movement by workers of the ant, Formica opaciventris. Amer. Zool., 4(3): 162.

1965 Observations on Microtus nesting in ant mounds. Psyche, 72(2): 127-132.

Simon, James R.

The American Elk or Wapiti. Wildlife Series No. 1, Jackson Hole Wildlife Park.

The Wyoming or Yellowstone Moose. Wildlife Series No. 2, Jackson Hole Wildlife Park.

Smith, Dixie R.

1959 Changes in interspecific associations as related to grazing pressures. Jour. Range Mgmt., 12(6): 309-311.

1960 Description and response to elk use of two mesic grassland and shrub communities in the Jackson Hole region of Wyoming. Northwest Science, 34(1): 25-36.

1961 Competition between cattle and game on elk winter range. Wyo. Ag. Exp. Sta. Bull. 377, 16 pp.

Solheim, W. G.

1960 Mycoflora Saximontanensis Exsiccata. Centum XI and XII. U. of Wyoming Publ., 24(3E4): 22-33; 34-55.

1970 Mycoflora Saximontanensis Exsiccata. Centum XIV. U. of Wyoming Publ., 36(4): 51-67. July 15.

Solheim, W. G. and George B. Cummins

1970 Mycoflora Saximontanensis Exsiccata. Centum XIII. U. of Wyoming Publ., 36(3): 37-50. July 15.

Mycoflora Saximontanensis Exsiccata. Centum XV. U. of Wyoming Publ., 36(5): 69-80. July 15. 
Spencer, Warren P.

1950 The Drosophila of Jackson Hole, Wyoming--a taxonomic and ecological survey. Am. Mid. Nat., 43(1): 79-87.

Stuart, Sidney A., Gordon A. McFeters, John E. Schillinger and David G. Stuart

1976 Aquatic indicator bacteria in the high alpine zone. Applied and Environmental Microbiology, 31(2): 163-167.

Sutton, John F. and Craig C. Black

1975 Paleontology of the earliest oligocene deposits in Jackson Hole, Wyoming. Part 1. Rodents exclusive of the Family Eomyidae. Annals of Carnegie Museum, 45(16): 299-315.

Thornton, Charles Stead

1956 Epidermal modifications in regenerating and in non-regenerating limbs of anuran larvae. J: Exp. Zool., 131(2): 373-394.

The relation of epidermal innervation to the regeneration of limb deplants in Amblystoma larvae. J. Exp. Zool., 133(2): 281-300.

1957 The effect of apical cap removal on limb regeneration in Amblystoma larvae. J. Exp. Zool., 134(2): 357-382.

1958 The inhibition of 1 imb regeneration in urodele larvae by localized irradiation with ultra-violet light. J. Exp. Zool., $137(1): 153-180$.

1960 Influence of an eccentric epidermal cap on limb regeneration in Amblystoma larvae. Dev. Biol., 2(6): 551-569.

Regeneration of asensory limbs of Amblystoma larvae. Copeia, No. 4, pp. 371-373, Dec. 30.

Thurmond, William

1967 Hypothalamic chromatophore-stimulating activity in the amphibians Hyla regilla and Ambystoma tigrinum. Gen. and Comp. Endocrinology, 8(2): 245-251.

Onset of chromatophore-stimulating activity by the hypothalamus and adenohypophysis in Hyla regilla and Ambystoma tigrinum.

Gen. and Comp. Endocrinology, 8(2): 252-257.

Intermedin-like activity by the pars distalis of the salamarder Ambystoma tigrinum. Amer. Zool., 7(2): 7, May.

1968 Onset of melanophore-stimulating activity of the pars dista is and pars intermedia of the tiger salamander Ambystoma triginum melanostictum. Amer. Zool., 8(4): 113, November.

Tiner, Jack $D$.

1951 Observations on larval carnivore ascarids in rodents. Jour. Parasit., 37 (Sup.): 21-22. 
Tiner, Jack D. (Cont.)

1952 Speciation in the genus Ascaris: Additional experimental and morphological criteria. Jour. Parasit., 38(Sup.): 57.

1953 The migration, distribution in the brain, and growth of ascarid larvae in rodents. Jour. Infect. Dis., 92: 105-113.

Fatalities in rodents caused by larval Ascaris in the central nervous system. Jour. Mammal., 34: 153-167.

Wi ley, Robert W.

1969 Snake River Cutthroat Trout Study, Part II: An ecological evaluation of the Snake Rive- cutthroat trout fishery with emphasis on harvest. Coop. Res. Proj. \#4, Wyo. Game E Fish Com., June 1969.

Williams, 0 lwen

1959 Food habits of the deer mouse. Jour. of Mammal., 40(3): 413-419. 